\title{
A Study on the Performance of Crusher Dust In Place Of Sand and Red Soil as A Subgrade And Fill Material
}

\author{
*P.V.V. Satyanarayana, **N. Pradeep, N. Nandhini, \\ *Professor, **Post graduate students Dept. of Civil Engineering, AU.
}

\begin{abstract}
Crusher dust as a geotechnical material for its bulk utilization in construction activities and to assess its performance tests like compaction, strength have been performed to suit as a fill and sub-grade material in place of sand and natural soil. Parameters like density, angle of shearing resistance, CBR, drainage, etc., were performed. From the test results it was identified that crusher dust achieved higher densities and maintained high shearing resistance value with wider variation of moisture contents. By attaining high CBR, strength, drainage as that of sand, crusher dust can be used as an alternative material in geotechnical activities.
\end{abstract}

\section{Introduction:}

Durability of a structure requires good foundation or foundation material to transfer load smoothly without causing any undue deformations. To meet the demands of the population lot of civil engineering structures like building, roads, embankments, etc., are to be required for the need of the people. Structures constructed on poor grounds are subjected to failures due to settlements increase the maintenance cost. To increase the bearing strength of the ground as a foundation material and to reduce the plastic deformation due to presence of fines in the natural soils as fill materials, alternative materials like fly ash, pond ash, crusher dust etc., have been gaining importance now-a-days. Availability of these wastes in large quantities encourages the geotechnical engineers for their bulk utilization in construction activities in place of natural soils. In the present investigation an attempt is made to study the performance of crusher dust as geo technical material in construction activities. Crusher dust has wider applications in the areas of infrastructural facilities as a retaining material without Reinforcement, fill material in Highway construction, etc. In north coastal districts of Andhra Pradesh abundant quantities of crusher dust has been produced and its production is nearly 24 lakh tones per annum.

Wider studies have been made on crusher dust by researches like Shanker and Ali(1992), Rao. et.al(1996), Nagaraj T.S et.al(1996,2000) as an alternative material in place of sand. Illangovan and Nagamani (2006) studied natural sand crusher dust as a replacement to sand in concrete. Wood S.A.et.al (1993) studied the use of crusher dust in this construction. Moorthy N.V.R. et.al (2002) studied the interaction of rock flour with geotextiles in a potential area of application. Sridharan et.al $(2005,2006)$ studied crusher dust in highway construction. Soosan et.al (2001) studied crusher dust as embankment and sub-base material in highway constructions. Praveen Kumar. et.al (2006) studied crusher dust as a sub-base material by conducting CBR tests. In the present investigation geotechnical characterizations like compaction, strength, seepage, gradation etc., have been performed for its utilization as a fill material as sub-grade material in place of sand natural soils.

\section{Study area:}

North coastal districts of Andhra Pradesh have been with many pockets of Red soil deposits. Most of the deposits contain fine sand and silt particles with little amount of clay particles. Small amount of clay and silt particles make these Red soils hard at dry conditions and collapse on wet (saturated) condition. Roads constructed on these deposits using these soils as sub-grade material subjected to number of failures. In the present investigation Red soil obtained from Visakhapatnam are subjected for gradation, compaction and strength characteristics. The results are shown in the table -1 and figure $1 \& 2$ 


\section{Geo technical properties of red soils:}

\begin{tabular}{|c|c|}
\hline Property & Values \\
\hline \multicolumn{2}{|l|}{ Grain size distribution } \\
\hline Gravel (\%) & 0 \\
\hline Sand (\%) & 74 \\
\hline Fines $(\%)$ & 26 \\
\hline a. $\quad$ Silt $(\%)$ & 21 \\
\hline b. $\quad$ Clay $(\%)$ & 5 \\
\hline \multicolumn{2}{|l|}{ Consistency: } \\
\hline Liquid Limit (\%) & 24 \\
\hline Plastic Limit (\%) & 18 \\
\hline I.S Classification & SM-SC \\
\hline Plasicity index & 6 \\
\hline Specific gravity & 2.67 \\
\hline \multicolumn{2}{|l|}{ Compaction characteristics } \\
\hline Optimum moisture content (OMC) (\%) & 8.5 \\
\hline Maximum dry density (MDD) (g/cc) & 1.9 \\
\hline California bearing ratio (CBR) (\%) (unsoaked) & 10.0 \\
\hline California bearing ratio (CBR) (\%) (Soaked) & 3.0 \\
\hline Apparent Cohesion(C) & 1.0 \\
\hline Angle of internal friction (Ø) & 29 \\
\hline Coefficient of permeability $(\mathrm{k}, \mathrm{cm} / \mathrm{s})$ & $3.4 \times 10^{-5}$ \\
\hline
\end{tabular}

Table-1

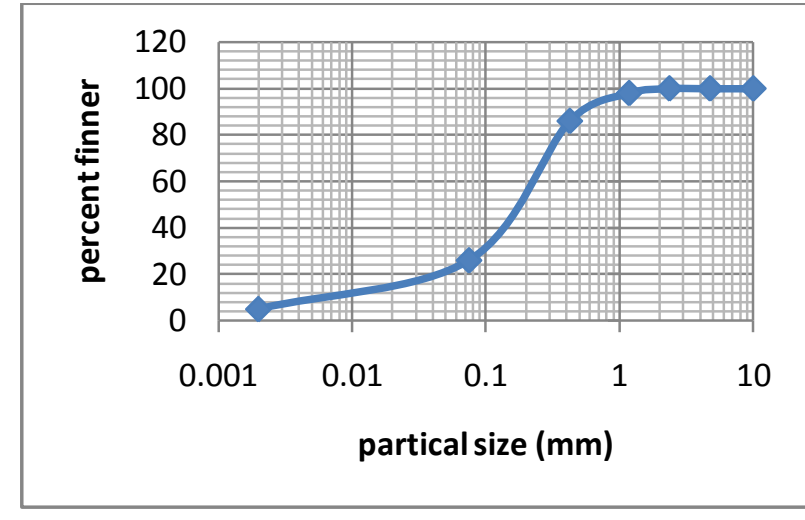

Fig-1 particle size distribution curve of Red soil

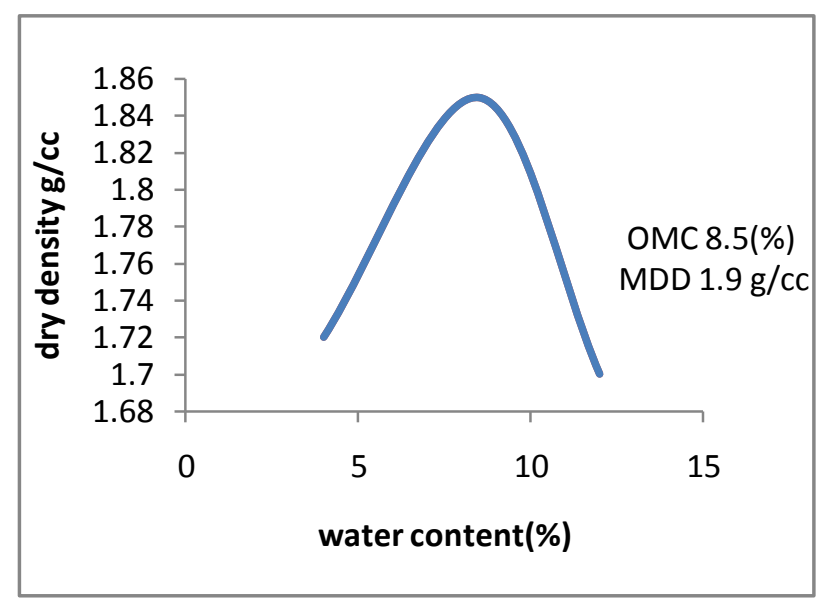

Fig-2 compaction curve of $\operatorname{Red}$ soil

Variation of strength parameters of Red soil:

\begin{tabular}{|c|c|c|c|c|}
\hline Water content (\%) & 8.5 & 10 & 12 & 14 \\
\hline $\mathrm{C}\left(\mathrm{t} / \mathrm{m}^{2}\right)$ & 1.0 & 0.8 & 0.5 & 0 \\
\hline$\varnothing($ deg.) & 29 & 27 & 25 & 22 \\
\hline
\end{tabular}

Table-2

From the test results it is identified that red soil contains $74 \%$ of fine sand particles, $21 \%$ of silt and $5 \%$ of clay particles and it is having low plasticity characteristics( $\mathrm{Ip}=6<7)$. It exhibited high maximum dry density of $1.9 \mathrm{~g} / \mathrm{cc}$ and high shear strength parameters.

When the soil sample subjected for strength parameters like C, Ø and CBR on wet conditions the following identifications are made. When the sample tested at moisture contents higher than optimum moisture contents the apparent cohesion(C) and angle of internal friction (Ø) values are decreasing. Moisture content just above OMC (10\%) has little decrease where as at $14 \%$ abnormal decreases in shear strength parameters were observed. This is due to loss of cohesion and friction between particles due to excess moisture contents between the particles. Similarly in the case of CBR value it has maximum value $(10 \%)$ at unsoaked condition where as at soaked conditions it has a CBR value of 3 .

To introduce materials like crusher dust and sand have been selected to study their behaviour with respect to gradation, compaction, strength parameters to suit as sub-grade materials and also to compare the result of crusher dust with respective sand as a replacement to sand in geotechnical constructional activities 


\section{Materials:}

Crusher Dust was obtained from local stone crushing plants near Anakapalli, Visakhapatnam district, Andhra Pradesh and sand sample was collected from river Nagavali, Srikakulam, Andhra Pradesh

\section{Results:}

\subsection{Crusher dust :}

Crusher dust was collected from crusher stone plants near Anakapalli, Vishakhapatnam, Andhra Pradesh. The collected crusher dust was dried and subjected to various geo-technical characterizations such as gradation, compaction, strength etc. The test results are shown in table-3 and fig $3 \& 4$.

\section{Geotechnical properties of crusher dust:}

\begin{tabular}{|c|c|}
\hline Property & Values \\
\hline \multicolumn{2}{|l|}{ Grain size distribution: } \\
\hline Gravel (\%) & 5 \\
\hline Sand (\%) & 90 \\
\hline Fines $(\%)$ & 5 \\
\hline a. Silt(\%) & 5 \\
\hline b.Clay $(\%)$ & 0 \\
\hline \multicolumn{2}{|l|}{ Consistency: } \\
\hline Liquid Limit (\%) & NP \\
\hline Plastic Limit (\%) & NP \\
\hline I.S Classification & SP \\
\hline Specific gravity & 2.64 \\
\hline \multicolumn{2}{|l|}{ Compaction characteristics: } \\
\hline Optimum moisture content (OMC) (\%) & 13 \\
\hline Maximum dry density (MDD) (g/cc) & 1.9 \\
\hline \multicolumn{2}{|l|}{ Shear parameters: } \\
\hline Angle of shearing resistance(deg) & 36 \\
\hline $\begin{array}{l}\text { California bearing ratio (CBR) (\%) } \\
\text { (Soaked) }\end{array}$ & 10 \\
\hline Coefficient of Uniformity $\left(\mathrm{C}_{\mathrm{u}}\right)$ & 15.6 \\
\hline Coefficient of Curvature $\left(\mathrm{C}_{\mathrm{c}}\right)$ & 2.85 \\
\hline
\end{tabular}

Table-3

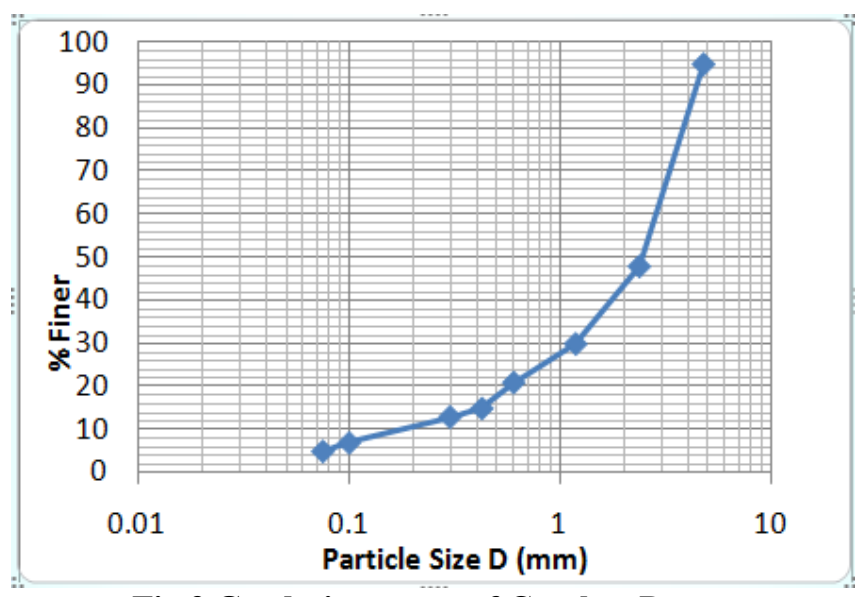

Fig 3 Gradation curve of Crusher Dust

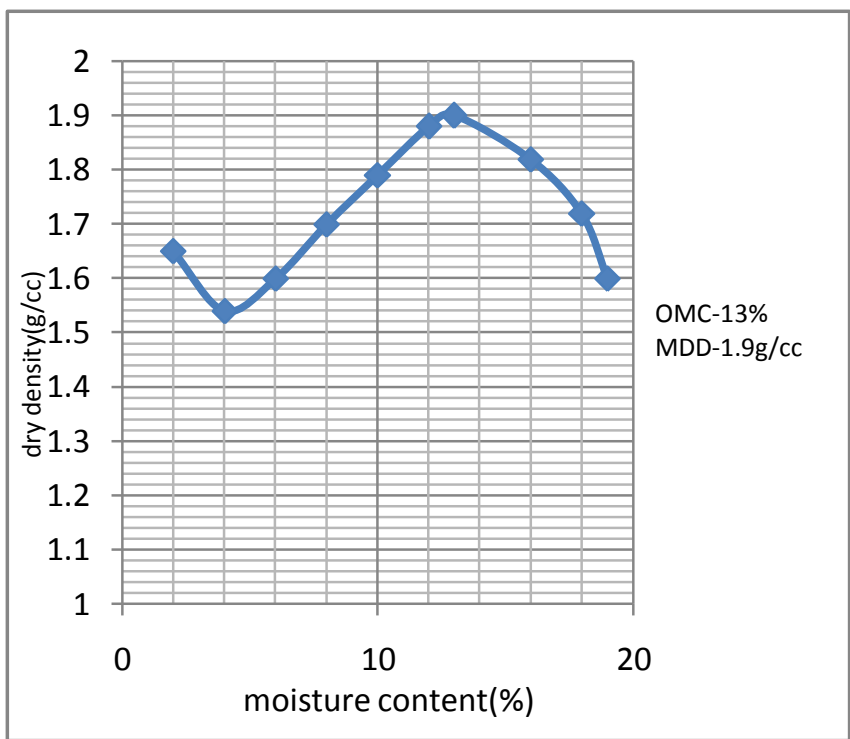

Fig 4 Compaction Curve of Crusher Dust

\subsection{Sand:}

The sand sample is collected from river Nagavali near srikakulam district and subjected for various geotechnical characteristics and the results are shown in table -4 and fig-5 and 6 


\section{Geotechnical properties of sand}

\begin{tabular}{|c|c|}
\hline Property & Values \\
\hline \multicolumn{2}{|l|}{ Grain size distribution: } \\
\hline Gravel (\%) & 0 \\
\hline Sand $(\%)$ & 98 \\
\hline Fines $(\%)$ & 2 \\
\hline a. Silt $(\%)$ & 2 \\
\hline b.Clay(\%) & 0 \\
\hline \multicolumn{2}{|l|}{ Consistency: } \\
\hline Liquid Limit (\%) & NP \\
\hline Plastic Limit (\%) & NP \\
\hline I.S Classification & SP \\
\hline Specific gravity & 2.66 \\
\hline \multicolumn{2}{|l|}{ Compaction characteristics: } \\
\hline Optimum moisture content (OMC) $(\%)$ & 6 \\
\hline Maximum dry density (MDD) (g/cc) & 1.75 \\
\hline \multicolumn{2}{|l|}{ Shear parameters: } \\
\hline Angle of shearing resistance(deg) & 34 \\
\hline California bearing ratio (CBR) $(\%)$ (Soaked) & 8 \\
\hline Coefficient of Uniformity $\left(\mathrm{C}_{\mathrm{u}}\right)$ & 2.07 \\
\hline Coefficient of Curvature $\left(\mathrm{C}_{\mathrm{c}}\right)$ & 1.41 \\
\hline
\end{tabular}

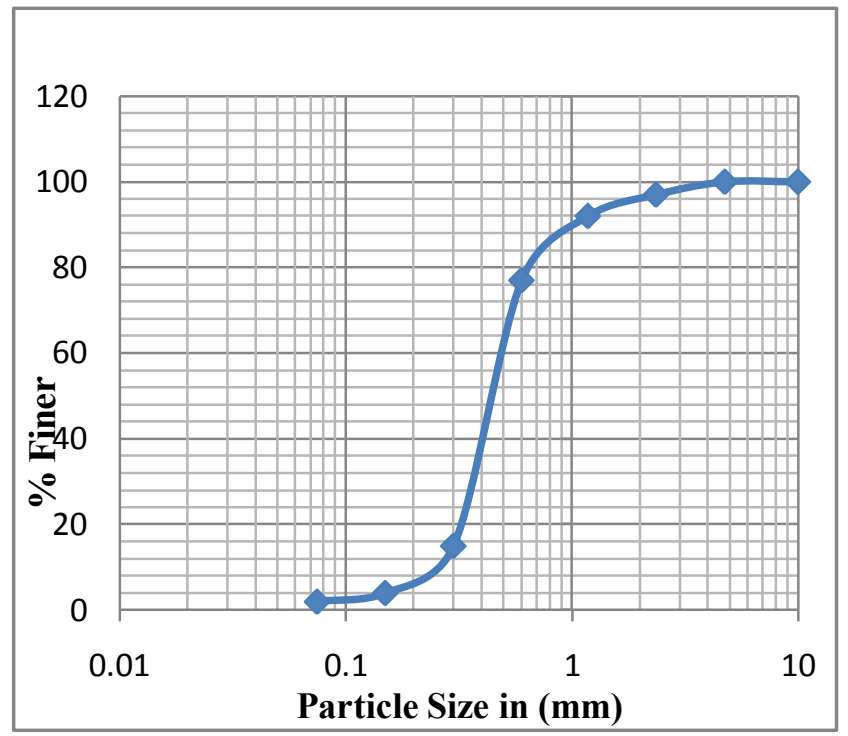

Fig-5 Gradation curve of sand

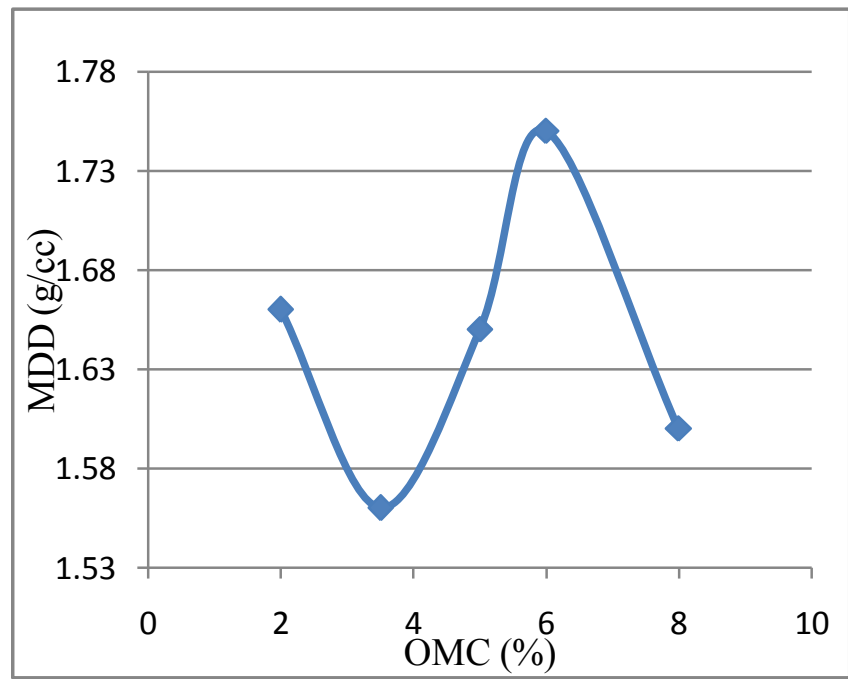

Table-4

Fig-6 Compaction Curve of sand

\subsection{Angle of shearing resistance:}

Crusher dust:

\begin{tabular}{|c|c|c|c|c|c|c|c|c|c|c|c|}
\hline Water content(\%) & 0 & 2 & 4 & 6 & 8 & 10 & 12 & 14 & 16 & 18 & 20 \\
\cline { 2 - 12 } & -12 & -10 & -8 & -6 & -4 & -2 & OMC & +2 & +4 & +6 & +8 \\
\hline $\begin{array}{c}\text { Angle of shearing } \\
\text { resistance(degree) }\end{array}$ & 29 & 30 & 31 & 32 & 34 & 35 & 36 & 34 & 32 & 30 & 28 \\
\hline
\end{tabular}

\section{Table-5}

Sand:

\begin{tabular}{|c|c|c|c|c|c|c|c|c|}
\hline \multirow{2}{*}{ Water content(\%) } & 0 & 2 & 4 & 6 & 8 & 10 & 12 & 14 \\
\cline { 2 - 8 } & -6 & -4 & -2 & OMC & +2 & +4 & +6 & +8 \\
\hline $\begin{array}{c}\text { Angle of shearing } \\
\text { resistance(degree) }\end{array}$ & 28 & 29 & 32 & 34 & 32 & 30 & 27 & 28 \\
\hline
\end{tabular}

\section{Table-6}




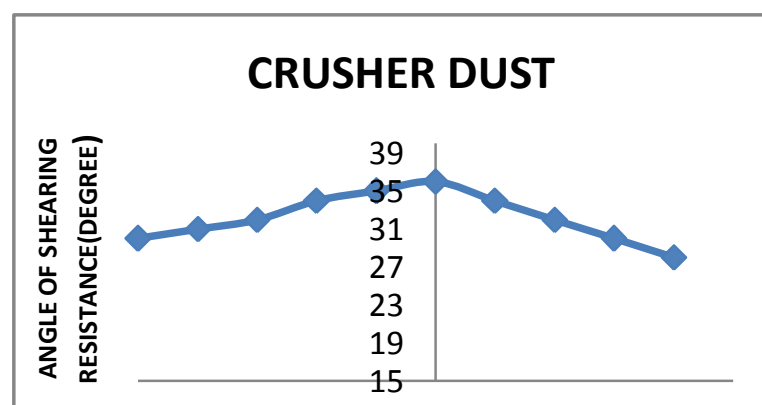

$-109-8-7-6-5-4-3-2-1012345678910$

water content(12\%)

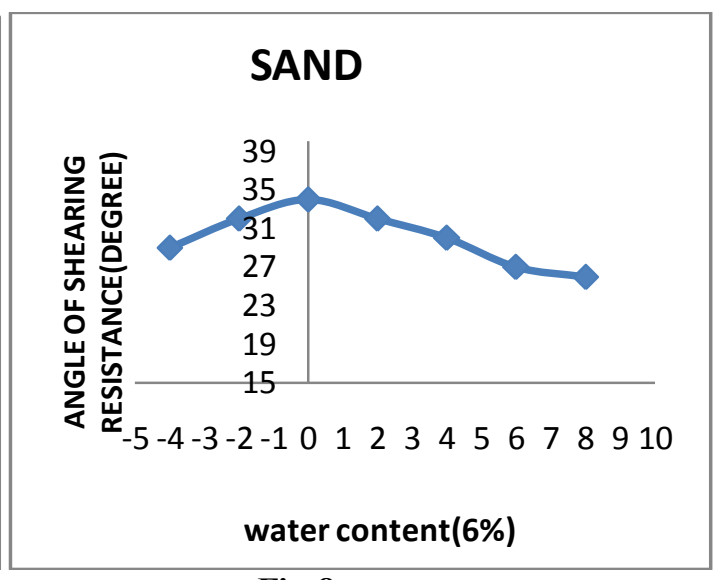

Fig-8

From the test results of crusher dust it is identified that at moisture contents less than optimum moisture content (dry side) a sharp decrease in angle of shearing resistance values were observed, whereas at moisture contents higher than optimum moisture content (wet side) a marginal decrease was observed. It is also identified that high angle of shearing resistance values were observed with variation of moisture contents on wet side of optimum moisture content i.e the crusher dust particles can with stand high densities at high moisture contents by maintaining high shearing resistance under shearing of particles. From the test result of sand it is observe that at higher and lower moisture contents with respective to optimum moisture content a sharp decrease in angle of shearing resistance values were observed. Compared with the results of crusher dust, sand exhibited high loss of shearing resistance for shallow range of moisture contents hence crusher dust offers more shearing resistance at wide range of moisture contents.

Comparing the results of crusher dust with Red soil loss of shear strength in terms of cohesion and friction is high at higher moisture contents (14\%), whereas crusher dust exhibited highest friction force at the $12 \%$ moisture content and maintained with a little decrease at $14 \%$ moisture content. From the CBR characteristics it is identified that crusher dust attained high CBR values(10\%) at high moisture contents compared to sand and red soils. Hence from the test results crusher dust performed better than sand and can be used as alternative material to sands in geotechnical applications such as sub grades and fill materials.

\section{Conclusion:}

Crusher dust particles are similar to sand particles and offer more shear strength at wider variation of moisture contents by maintain high dry densities and can with stand high strengths in terms of CBR and angle of shearing resistance which can be used as fill and sub grade material in place of Red soil and sand

\section{References:}

[1]. Collins R.J and Ciesilki, S.K (1994)-Recycling and use of waste materials and by-products in highway construction, synthesis of Highway Practice 1994, National Academy Press, Washington D.C

[2]. Illangovan R et.al (2006)-Studies on strength and behaviour of concrete by using quarry dust as fine aggregate. CE and CR journal, New Delhi. October .pp. 40-42.

[3]. IS 2720: Part 16: 1987-Methods of test for soil-Part 16: Laboratory determination of CBR.

[4]. IS 2720: Part 13: 1986-Methods of test for soils-Part 13: Direct Shear test.

[5]. IS 2720: Part 17: 1986-Methods of test for soils -Part 17: Laboratory determination of Permeability.

[6]. IS 2720: Part 4: 1985-Methods of test for soils-Part 4: Grain size analysis.

[7]. IS 2720: Part 8: 1983-Methods of test for determination of compaction characteristics.

[8]. IS 2720: Part 3: Sec 2: 1980-Test for soils- Part 3: Determination of Specific gravity- Section 1 Fine grained soils.

[9]. Moorthy N.V.R et.al (2002)-potential of rock flour for use in reinforced soil construction, journal of South East Asian geotechnical society, Vol.88,pp. 47-50.

[10]. Praveen Kumar, Satish Chandra and Vishal R. (2006)-Comparative study of different study of different sub-base materials. J.Mat. In civil engg. Vol.18, 576-580.

[11]. Soosan T.G, Jose B.T and Abraham B.M(2001)-Use of quarry dust in embankment and highway construction, Proceedings of Indian Geo-technical Conference, December, Indore, pp. 274-277.

[12]. Soosan T.G, Jose B.T and Abraham B.M(2000)-Improvement of ground and highway sub-bases using quarry waste, Proceedings of International seminar on civil engineering, ICCE, 2001, IISc. Bangalore, pp.730-737-July 2001.

[13]. Sridharan A and Soosan T.G and Babu, T.J(2006)-Shear strength studies on soil-quarry dust mixtures, journal of Geotechnical Engineering, Vol.24,pp. 1163-1179.

[14]. Sridharan A and Soosan T.G and Babu T.J(2005)-Utilization of quarry dust to improve the geotechnical properties of soils in highway construction, Canadian Geotechnical Journal, Vol.28,pp. 391-400.

[15]. Wood S.A and Marek C.R(1993)-Recovery and utilization of quarry by-products in highway construction, Synthesis of Highway practice 199, National Academy Press, Washington D.C. 